\title{
Pengaruh Strategi Promosi Stikom Interstudi terhadap Peningkatan EKUITAS MEREK
}

\author{
The EFfect Of Sticom Promotional Strategy InTERest In The Improvement OF BRAND EQUity \\ ${ }^{1}$ Soebiagdo, ${ }^{2}$ Poppy Ruliana
}

email: ${ }^{1}$ kabinex.comm@gmail.com, ${ }^{2}$ Poppyruliana30@gmail.com

\begin{abstract}
The purpose of this study is to determine and analyze the influence of STIKOM InterStudi promotion strategy to increase brand equity. The concept of promotional strategy according to Lamb, Hair, McDaniel (2001: 146), is a plan for optimal use of elements of advertising, public relations, personal sales and sales promotion ". Brand equity, according to David A. Aaker (1991), is "a series of brand assets and liabilities associated with a brand, its name and symbol, which add or subtract the value of a product or service to the company and / or its customer ". Aaker's definition implies that brand equity can be valuable to the company (company-based brand equity) and to the customer (customer-based brand equity). The approach used in this research is quantitative. The method used is explanative, and the type of research is survey. The population of this study are STIKOM InterStudi students as many as 1154 students and 92 sample students referring to Taro Yamane formula with Purposive Sampling technique. The data are processed by using SPSS 20.0 with Factor Analysis Menu, Alpha Cronbach, Descriptive Statistics and Inferential Statistics then presented in frequency table, mean value and regression analysis. Technique of data collecting done in primary and secondary. Primarily conducted through observation, questionnaire distribution, interview. While the secondary is done through literature and documentation. To analyze the data used Mixed Methods (Mixed Methods). Mixed method research is a good design to use if we try to base on the strength of both quantitative and qualitative data. The design of a mixed methods research design is a procedure for collecting, analyzing, "and mixing" quantitative and qualitative methods in a study or series of studies to understand the research problem (Cresswell \& Plano Clark, 2011). The results showed that the promotional strategy undertaken by STIKOM InterStudi had an effect on increasing Brand Equity, but the effect was too low, only $14.3 \%$. While the rest, as much as $85.7 \%$ influenced by other factors not examined in this study. Dimensions that have a significant influence in Brand Equity improvement are the dimensions of Word of Mouth (X2), while the other two dimensions: Advertising (X1) and Digital Advertising (X3), partially have no significant effect on Brand Equity STIKOM InterStudi.
\end{abstract}

Keywords: Conventional Advertising, Digital Advertising and Word of Mouth STIKOM InterStudi, Brand Equity

\footnotetext{
Abstrak. Tujuan penelitian ini adalah Untuk mengetahui dan menganalisis pengaruh strategi promosi STIKOM InterStudi terhadap peningkatan ekuitas merek. Konsep strategi promosi menurut Lamb, Hair, McDaniel (2001 : 146), adalah rencana untuk penggunaan yang optimal dari elemen-elemen periklanan, hubungan masyarakat, penjualan pribadi dan promosi penjualan”. Sedangkan Brand equity menurut David A. Aaker (1991) adalah "serangkaian asset dan kewajiban (liabilities) merek yang terkait dengan sebuah merek, nama dan simbolnya, yang menambah atau mengurangi nilai yang diberikan sebuah produk atau jasa kepada perusahaan dan /atau pelanggan perusahaan tersebut". Definisi Aaker menyiratkan bahwa brand equity bisa bernilai bagi perusahaan (company based brand equity) dan bagi konsumen (customer-based brand equity). Pendekatan yang diguanakan dalam penelitian ini adalah kuantitatif. Metode yang digunakan eksplanatif, dan
} 
jenis penelitiannya adalah survey. Populasi penelitian ini adalah siswa STIKOM InterStudi sebanyak 1154 siswa dan 92 sampel siswa mengacu pada formula Taro Yamane dengan teknik Purposive Sampling. Data yang diolah dengan menggunakan SPSS 20.0 dengan Factor Analysis Menu, Alpha Cronbach, Statistik Deskriptif dan Statistik Inferensial kemudian disajikan pada tabel frekuensi, nilai mean dan analisis regresi. Teknik pengumpulan data dilakukan secara primer dan sekunder. Secara primer dilakukan melalui observasi, penyebaran kuesioner, wawancara. Sedangkan secara sekunder dilakukan melalui kepustakaan dan dokumentasi. Untuk menganalisis data digunakan Metode Campuran (Mixed Methods). Penelitian metode campuran adalah suatu rancangan yang baik untuk digunakan jika kita mencoba mendasarkan pada kekuatan data kuantitatif maupun kualitatif. Rancangan penelitian metode campuran (mixed methods research design) adalah suatu prosedur untuk mengumpulkan, menganalisis, "dan mencampur" metode kuantitatif dan kualitatif dalam suatu penelitian atau serangkaian penelitian untuk memahami permasalahan penelitian (Cresswell \& Plano Clark, 2011). Hasil penelitian menunjukkan bahwa strategi promosi yang dilakukan oleh STIKOM InterStudi berpengaruh dalam meningkatkan Brand Equity, namun pengaruhnya terlalu rendah, hanya memiliki 14,3\%. Sedangkan sisanya, sebanyak 85,7\% dipengaruhi oleh faktor lain yang tidak diteliti dalam penelitian ini. Dimensi yang memiliki pengaruh signifikan dalam peningkatan Brand Equity adalah dimensi Word of Mouth (X2), sedangkan dua dimensi lainnya: Periklanan (X1) dan Digital Advertising (X3), secara parsial tidak berpengaruh signifikan dalam peningkatan Brand Equity STIKOM InterStudi.

Kata kunci: Periklanan Konvensional, Periklanan Digital dan Kata Mulut STIKOM InterStudi, Brand Equity

\section{Pendahuluan}

$\begin{array}{crr}\begin{array}{c}\text { Sekolah } \\ \text { Komunikasi }\end{array} & \begin{array}{c}\text { Tinggi } \\ \text { InterStudi }\end{array} & \begin{array}{r}\text { Ilmu } \\ \text { adalah }\end{array}\end{array}$
organisasi pendidikan tinggi dibidang ilmu komunikasi yang mempunyai berbagai program pendidikan Strata 1, yang terdiri dari jurusan Public Relations (kehumasan), konsentrasi Advertising (Periklanan), Konsentrasi Broadcasting (Penyiaran) , serta konsentrasi Business Communication (Komunikasi Bisnis), disamping itu STIKOM InterStudi juga mempunyai program pendidikan strata 2 yang terdiri dari bidang Strategic Communication serta Entertainment Communication.

Tantangan terbesar dalam merencanakan serta menyusun strategi promosi yang kreatif serta program promosi dalam bentuk komunikasi secara terpadu adalah menetukan strategi dan program promosi yang sekiranya paling efektif untuk menghasilkan dampak terbesar terhadap penjualan. Bagian promosi STIKOM
InterStudi dalam usahanya untuk menarik calon mahasiswa telah melakukan berbagai program promosi ditengah persaingan dari berbagai Perguruan Tinggi baik Negeri maupun swasta guna merebut ceruk pasar yang ada. Paradigma pemasaranpun telah berubah dari orientasi terhadap produk menjadi orientasi terhadap merek, produk yang memiliki ekuitas merek yang kuat akan lebih mudah memenangkan persaingan. Demikian pula halnya dengan strategi promosi yang telah dilaksanakan oleh Sekolah Tinggi Ilmu Komunikasi InterStudi, apakah strategi promosi tersebut telah mampu menghasilkan ekuitas merek yang kuat dimata para calon mahasiswa? Dalam era digital saat ini, konsep promosi selalu berkiblat kepada langkah-langkah dalam mengembangkan kekuatan on-line marketing maupun off-line marketingsecara seimbang, onlinemarketing merupakan bentuk 
kampanye melalui e-marketing dengan memanfaatkan Search Engine Optimization (SEO), e-mail, Internet TV dan lain-lain, sedangkan off-line marketing merupakan kegiatan pemasaran melalui promosi Above The Line dan Below The Line.

Promosi STIKOM InterStudi juga telah melakukan berbagai jenis promosi melalui media Above The Line (Lini Atas), antara lain meliputi pemasangan iklan baik melalui media televisi maupun media cetak termasuk didalamnya penggunaan berbagai surat kabar maupun majalah, demikian pula halnya dengan media Below The Line (lini bawah), melalui distribusi brosur dan leaflet kepada khalayak sasaran, termasuk didalamnya mengikuti berbagai event pameran pendidikan serta forum pertemuan dengan calon mahasiswa dari berbagai Sekolah Lanjutan Umum yang menjadi khalayak sasaran promosi STIKOM InterStudi, disamping itu berbagai event inhousepun dalam bentuk program INVITE (InterStudi Visit Training and Edutainment) telah dilakukan dengan mengundang para siswa Sekolah Menengah Atas untuk mengenal lebih dekat kampus STIKOM InterStudi, demikian pula halnya dengan promosi melalui media sosial pun telah dilaksanakan secara periodik, namun hasil yang diharapkan dirasakan belum memenuhi sasaran yang telah dicanangkan. Sesuai dengan data yang diperoleh dari bagian promosi STIKOM InterStudi dapat diketahui bahwa dalam 4 tahun terakhir terhitung sejak tahun 2012 sampai dengan tahun 2015, jumlah mahasiswa baru cenderung stabil dan tidak mengalami penurunan yang berarti, dengan jumlah mahasiswa berkisar antara 355 orang sampai dengan 324 orang mahasiswa, namun pada tahun 2016 telah terjadi penurunan jumlah mahasiswa baru menjadi sebesar 249 orang.

Menarik untuk dikaji lebih lanjut keberadaan data peringkat akreditasi dari berbagai Perguruan Tinggi baik Negeri maupun Swasta jurusan ilmu komunikasi di Indonesia (https://bisfren.com/jurusan-ilmu-

komunikasi.html), urutan teratas Perguruan Tinggi Peringkat Akreditasi A meliputi 25 universitas yang terdiri dari 11 (sebelas) Universitas Negeri antara lain Universitas Airlangga Surabaya, Universitas Padjadjaran Bandung, Universitas Lampung Bandar Lampung, dan lain-lain, serta 14 Universitas swasta antara lain meliputi Universitas Al-Azhar Jakarta, Universitas Muhammadiyah Prof. Dr. Hamka, Universitas Prof. Dr. Moestopo, dan lain lain.

Saat ini media promosi telah berubah dari one way communication menjadi berbagai bentuk komunikasi yang banyak melibatkan Target Audiences, media massa pun telah berubah menjadi lebih spesifik dan terspesialisasi (niche) yang terpusat kepada spesifik Target Audience, dominasi produsen pun telah berubah menjadi dominasi konsumen, fokus promosi yang bersifat umum telah terkonsentrasi menjadi kegiatan Data Based Marketing yang dikenal dengan kegiatan Customer Relationship Marketing serta mengacu kepada pemeliharaan hubungan jangka panjang yang baik dengan konsumen atau mahasiswa yang mengikuti pendidikan di STIKOM InterStudi, pada intinya kegiatan promosi harus terus menerus memahami kebutuhan dan keinginan konsumen, termasuk pula kebutuhan dan keinginan yang menjadi harapan dimasa mendatang.Oleh karena itu, kegiatan promosi harus sejalan dengan rencana pemasaran serta diarahkan dan dikendalikan dengan baik, ditujukan 
untuk meningkatkan ekuitas merek produknya sehingga dapat memberikan kontribusi yang tinggi dalam upaya meningkatkan volume penjualan produknya.

$$
\text { Konsumen di Indonesia }
$$
terbilang unik, dimana keunikan tersebut akan memberikan pertimbangan yang matang bagi sebuah lembaga pendidikan dalam membuat strategi promosi yang tepat untuk mencapai target yang diinginkan. Salah satu karakter yang unik tersebut adalah kebiasaan menjalin hubungan sosial dan berkumpul. Kebiasaan tersebut telah menjadi sarana komunikasi yang efektif dan menguntungkan perusahaan, salah satu strategi promosi yang dapat digunakan adalah strategi Word of Mouth (WOM) yang ditujukan kepada teman, tokoh, keluarga dan lain-lainnya. Berdasarkan pengamatan sepintas, kebanyakan mahasiswa memilih pendidikan di STIKOM InterStudi lebih mempercayai referensi dari teman atau orang yang dikenal termasuk keluarga yang dianggap sebagai sumber informasi yang paling kredibel dan layak dipercaya. Sehingga dapat dipastikan bahwasanya konsumen atau calon mahasiswa yang mendengar cerita yang tidak baik perihal suatu merek dari teman atau keluarganya memutuskan untuk tidak bergabung dengan lembaga pendidikan tersebut.

Salah satu definisi Brand Equity (Ekuitas Merek) yang paling banyak dikutip adalah definisi versi David A. Aaker (1991) yang menyatakan bahwa Ekuitas Merek adalah serangkaian asset dan kewajiban (liabilities) merek yang terkait dengan sebuah merek, nama dan simbolnya, yang menambah atau mengurangi nilai yang diberikan sebuah produk atau jasa kepada pelanggan perusahaan tersebut, Aaker menyiratkan bahwa ekuitas merek bisa bernilai bagi perusahaan serta bagi konsumennya, Aaker mengklasifikasikan elemen- elemen ekuitas merek kedalam empat dimensi, yaitu brand awareness, perceived quality, brand associations dan brand loyalty. Hal ini biasanya tercermin dari cara konsumen berfikir, merasa dan bertindak terhadap harga, pemilihan merek, pangsa pasar dan peluang yang dimiliki perusahaan.

Oleh karena itu, peneliti berusaha mengungkapkan bagaimana penerapan strategi promosi yang digunakan oleh bagian promosi STIKOM InterStudi apakah dapat meningkatkan ekuitas merek terhadap produk, oleh sebab itu perlu diperhatikan faktor-faktor yang dapat mempengaruhi ekuitas merek antara lain meliputi Brand Awareness,Perceived Quality, Brand Association dan Brand Loyalty terhadap produknya. Penelitian ini diharapkan mampu mengungkap pengaruh penerapan strategi promosi STIKOM InterStudi terhadap peningkatan ekuitas merek produknya.

\section{Tinjauan Literatur}

Menurut Lamb, Hair, McDaniel (2001 :147), "bauran promosi adalah kombinasi dari alat promosi termasuk periklanan, hubungan masyarakat, dan promosi penjualan yang digunakan untuk mencapai pasar sasaran dan memenuhi tujuan organisasi secara keseluruhan". Sementara menurut Kotler \& Armstrong (2002:656) variabel-variabel yang ada di dalam promotional mix ada lima, yaitu:

1. Periklanan (advertising) Segala biaya yang harus dikel uarkan sponsor untuk melakuk an presentasi dan promosi non pribadi dalam bentuk gagasan, barang atau jasa.

2. Penjualan Personal (personal selling)

Presentasi pribadi oleh para $\mathrm{w}$ iraniaga perusahaan dalam ran gka 
mensukseskan penjualan dan membangun hubungan denga $n$ pelanggan.

3. Promosi penjualan (sales promotion)

Insentif jangka pendek untuk mendorong pembelian atau penjualan suatu produk atau jasa.

4. Hubungan masyarakat (public relation)

Membangun hubungan baik dengan publik terkait untuk memperoleh dukungan, membangun "citra perusahaan" yang baik dan menangani atau menyingkirkan gosip, cerita dan peristiwa yang dapat merugikan.

5. Pemasaran langsung (direct marketing)

Komunikasi langsung dengan pelanggan yang diincar secara khusus untuk memperoleh tanggapan langsung.

Dari dimensi strategi promosi tersebut, peneliti hanya memfokuskan pada periklanan (advertising). Menurut Ralph S.Alexander (1965), Iklan atau advertising dapat didefinisikan sebagai "any paid form of non-personal communication about an organization, product, servive or idea by an identified sponsor", yang berarti iklan adalah setiap bentuk komunikasi non-personal mengenai suatu organisasi, produk, layanan atau ide yang dibayar oleh satu sponsor yang diketahui. Adapun maksud "dibayar" pada definisi tersebut menunjukkan fakta bahwa ruang atau waktu bagi suatu pesan iklan pada umumnya harus dibeli, sedangkan maksud kata "non-personal" berarti iklan melibatkan media massa (TV, radio, majalah, koran) yang dapat mengirimkan pesan kepada sejumlah besar kelompok individu pada saat yang bersamaan. Selain media tersebut,digital Media Advertising merupakan sebuah sistem periklanan berbasis network dengan tujuan untuk mengubah media promosi konvensional ke media promosi digital. Ada beberapa media yang digunakan sebagai tempat melakukan promosi, antara lain Facebook, Twitter, situs web dan alternatif yang lainnya. Dalam pengembangan membentuk suatu usaha, sebuah perusahaan harus bisa memanfaatkan kekuatannya guna mengambil keuntungan dari peluang yang ada. Konsep pemasaran AIDA'S dalam dunia digital periklanan adalah bertujuan untuk memberikan kepuasan kepada pelanggan serta memberikan keuntungan bagi perusahaan, Dengan demikian konsep AIDA'S terdiri dari lima komponen sebagai berikut :

1. Attention (perhatian)

Pertama kali konsumen dihubungi atau ditawari oleh perusahaan tertentu, sehingga muncul perhatian (attention) pada diri konsumen . (Galaksi, 2009:1). Pada tahap perhatian perusahaan berusaha agar calon konsumen memperhatikan penawaran yang dilakukannya. Didalam dunia digital, periklanan membangun kesadaran konsumen dengan memasang iklan terlebih dahulu dimedia on-line sesuai dengan kebutuhan frekuensi penayangan yang mampu menarik perhatian calon konsumen.

2. Interest (Ketertarikan)

Merupakan tahap timbulnya minat konsumen terhadap produk yang sudah diperhatikan oleh calaon konsumen (Galaksi, 2009:1). Pada tahap ini perusahaan berusaha meningkatkan perhatian calon konsumen menjadi minat dengan cara menciptakan suasana yang menyenangkan 
dengan mendengarkan atau memahami kebutuhan konsumen. Hal tersebut akan muncul setelah konsumen terbangun tingkat kesadarannya, melalui system online konsumen langsung berusaha mencari informasi-informasi di pasar, termasuk pula mencari tahu tentang produk melalui mesin pencari atau search engine (Google, Yahoo, dll) dan jejaring social (Facebook, Twitter, dll).

3. Desire (Keinginan)

Menurut Khani, adanya ketertarikan tersebut akan menimbulkan hasrat, keinginan (desire) konsumen untuk membeli dan menggunakan produk yang ditawarkan oleh perusahaan tersebut.. Sistim online ditandai dengan mencari keterangan lengkap tentang produk atau jasa melalui situs web.

4. Action (Tindakan)

Pada tahap tindakan (action), perusahaan harus dapat mewujudkan kebutuhan dan harapan konsumen dan memberikan keyakinan bahwa barang, jasa dan ide yang dibeli merupakan langkah yang tepat yang dapat memberikan keuntungan bagi konsumen.

5. Kepuasan (Satisfaction)

Pada tahap kepuasan perusahaan harus dapat memastikan bahwa kualitas barang, jasa dan ide yang dibeli sesuai dengan harapan konsumen.

Strategi promosi lainnya yang bias digunakan dalam periklanan adalah Word of Mouth . Word of Mouth adalah komunikasi dari orang ke orang antara sumber pesan, penerima pesan dimana penerima pesan menerima pesan dengan sukarela mengenai suatu produk, layanan atau merek.

Menurut Word of Mouth Marketing Association (WOMMA), dalam Haryadi dan Fatmawati (2008), mendefinisikan WOM sebagai usaha pemasaran yang memicu konsumen untuk membicarakan, mempromosikan, merekomendasikan dan menjual produk atau merek kita kepada pelanggan lainnya. Kotler \& Keller (2007), mengemukakan bahwa

Word of Mouth Communication atau komunikasi dari mulut kemulut merupakan proses komunikasi yang berupa pemberian rekomendasi baik secara individu maupun kelompok terhadap suatu produk atau jasa yang bertujuan untuk memberikan informasi secara personal. Menurut Kotler \& Keller (2007), saluran komunikasi personal yang berupa ucapan atau perkataan dari mulut ke mulut dapat menjadi metode promosi yang efektif karena pada umumnya disampaikan dari konsumen dan untuk konsumen, sehingga konsumen atau pelanggan itu komunikasi personal dari mulut ke mulut tidak membutuhkan biaya yang besar, karena dengan adanya konsumen yang puas maka segala bentuk rujukan atau referensi terhadap suatu produk atau perusahaan akan dapat lebih mudah tersebar kepada konsumen-konsumen lainnya.

Siverman (2001), mengemukakan efektif tidaknya komunikasi word of mouth (WOM) tidak terlepas dari sifat komunikasi tersebut yang didefinisikan sebagai berikut : "A form of interpersonal communication consumers concerning their personal experiences with a firm or a product " yang berarti bahwa komunikasi dari mulut ke mulut merupakan komunikasi interpersonal yang terjadi antara individu satu dengan individu yang lain berdasarkan pada pengalaman yang dimiliki oleh masing- 
masing individu terhadap suatu perusahaan atau produk baik yang berupa barang maupun jasa.

Dalam penelitian yang dilakukan Goyette, Ricard, Bergeron dan Marticotte (2010) tentang skala pengukuran WOM, mereka mengusulkan beberapa indikator untuk mengukur WOM, antara lain:

\section{WOM Content}

Isi percakapan atau konten pembahasan suatu produk seperti jenis, kualitas, harga dan lain-lain.

\section{Negative Valence WOM}

Penyampaian hal-hal negatif kepada orang lain tentang suatu produk yang disebabkan oleh ketidak mampuan produk tersebut untuk memenuhi ekspektasi konsumen.

\section{Positive Valence WOM}

Penilaian positif sebagai efek dari kepuasan yang didapatkan konsumen yang dituangkan dalam percakapan sehari-hari seperti pemberian rekomendasi atau ajakan untuk membeli suatu produk atau jasa.

\section{WOM Intensity}

Intensitas atau volume percakapan mengenai suatu produk yang terjadi dalam percakapan sehari-hari.

. Salah satu definisi brand equity yang paling banyak dikutip adalah definisi versi David A. Aaker (1991) yang menyatakan bahwa brand equity adalah "serangkaian asset dan kewajiban (liabilities) merek yang terkait dengan sebuah merek, nama dan simbolnya, yang menambah atau mengurangi nilai yang diberikan sebuah produk atau jasa kepada perusahaan dan /atau pelanggan perusahaan tersebut". Definisi Aaker menyiratkan bahwa brand equity bisa bernilai bagi perusahaan (company based brand equity) dan bagi konsumen (customer-based brand equity).

Definisi dan elemen brand equity versi Aaker ini mengintegrasikan dimensi sikap dan perilaku, sementara kebanyakan operasionalisasi brand equity cenderung hanya berfokus pada salah satu diantara dimensi persepsi konsumen dan dimensi perilaku konsumen (misalnya, loyalitas merek, kesediaan membayar harga yang lebih mahal).

Menurut Aaker (2014:29) Merek yang kuat dapat menjadi basis keuntungan kompetitif dan memiliki profitabilitas jangka panjang untuk berkembang. Tujuan utama brand building adalah untuk membangun, meningkatkan atau menaikkan ekuitas merek yang dimensi utamanya adalah kesadaran, persepsi kualitas, asosiasi merek dan loyalitas merek, sebagai berikut :

1. Brand awareness

Yaitu kemampuan konsumen untuk mengenali atau mengingat bahwa sebuah merek merupakan anggota dari kategori produk tertentu. Keasadaran merek meruapakan satu asset yang sering diremehkan, namun telah ditunjukkan dapat mempengaruhi persepsi, rasa suka dan tingkah laku. Kesadaran merek tersebut dapat mempengaruhi apakah satu merek tersebut diingat kembali dalam suatu proses pembelian dan apakah merek tersebut berada diantara merek-merek yang dipertimbangkan pelanggan.

2. Perceived quality

Merupakan penilaian konsumen terhadap keunggulan atau superioritas produk secara keseluruhan. Oleh sebab itu, perceived quality didasarkan 
pada evaluasi subyektif konsumen terhadap kualitas produk (bukan dari pakar), persepsi kualitas adalah salah satu kunci dimensi ekuitas merek

3. Brand associations

Yaitu segala sesuatu yang terkait dengan memori terhadap sebuah merek. Brand associations berkaitan erat dengan brand image, yang didefinisikan sebagai serangkaian asosiasi merek dengan makna tertentu. Asosiasi merek memiliki tingkat kekuatan tertentu dan akan semakin kuat seiring dengan bertambahnya pengalaman konsumsi atau eksposur dengan merek spesifik. Asosiasi merek kualitas, pencitraan pengguna, keberagaman produk.

4. Brand loyalty

Yaitu "the attachment that a customer has to a brand" (Aaker, 1991, p.39), adalah inti dari setiap nilai merek karena begitu inti diperoleh maka loyalitas tersebut akan bertahan, keengganan pelanggan untuk berpindah merek akan memberikan keuntungan bagi merek yang sudah memperoleh loyalitas.

Berdasarkan tinjauan literature tersebut di atas, maka dapat ditarik suatu kerangka pemikiran sebagai berikut :

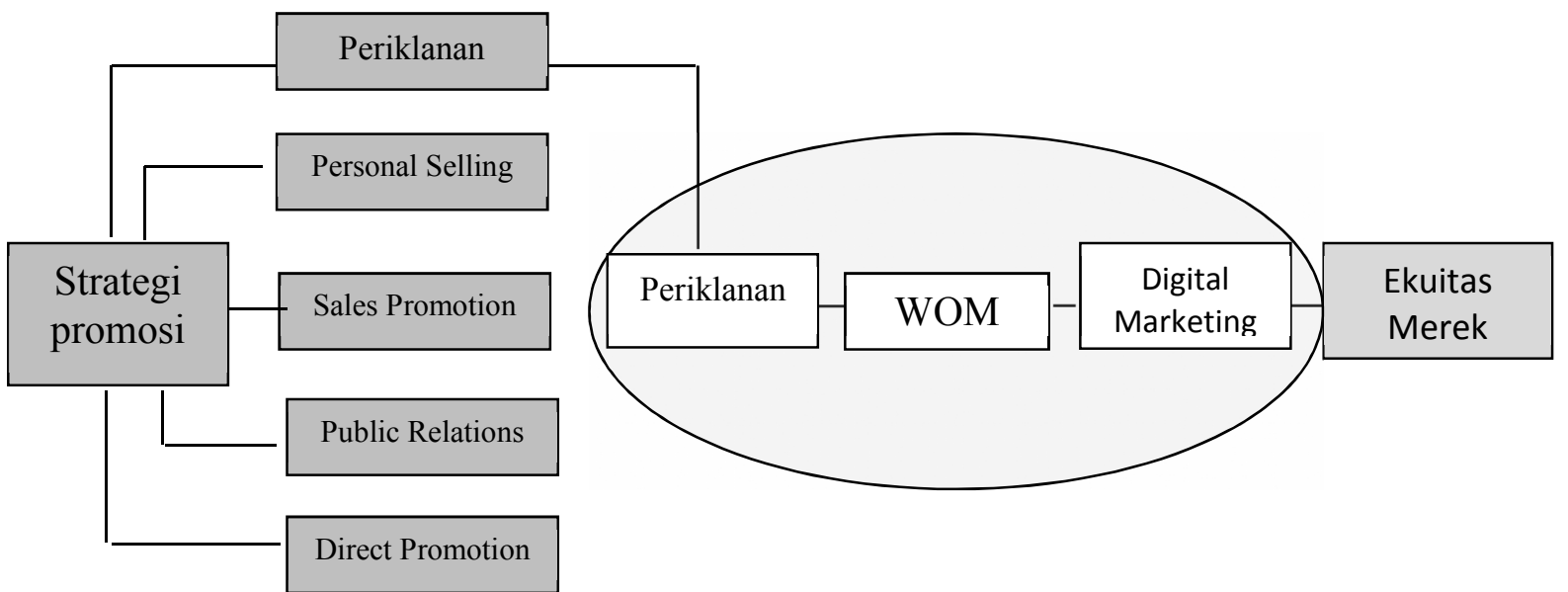

meliputi atribut produk, desain,

Kerangka Penelitian

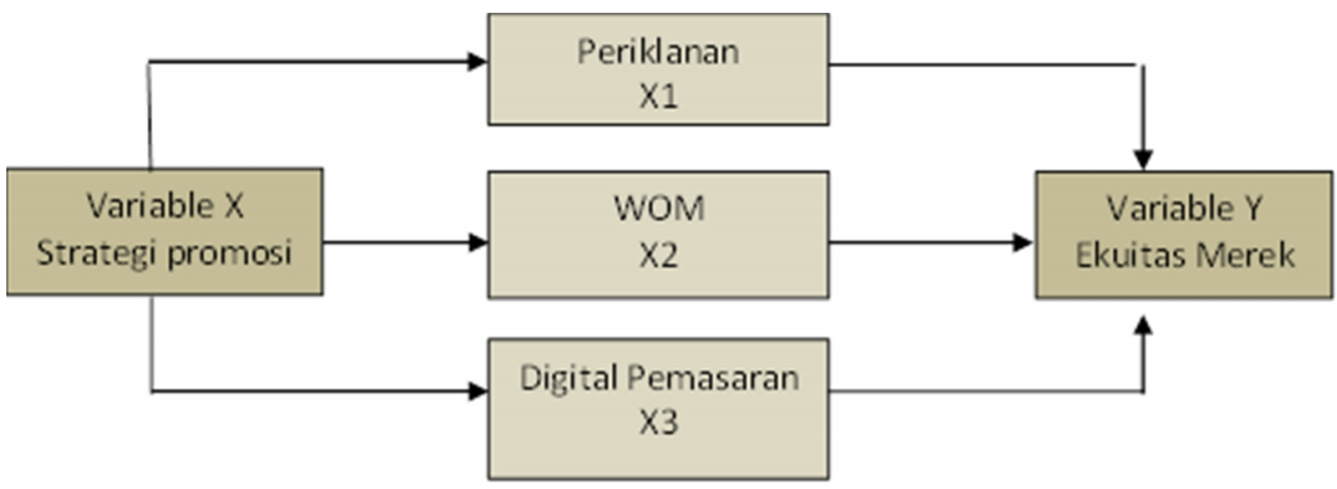


Dari kerangka penelitian tersebut di atas, maka hipotesis dalam penelitian ini adalah sebagai berikut :

$H o$ : Strategi promosi Sekolah Tinggi Ilmu Komunikasi InterStudi tidak berpengaruh terhadap peningkatan ekuitas merek.

$$
(\mathrm{r} \times \mathrm{y}=0)
$$

$H a$ : Strategi promosi Sekolah Tinggi Ilmu Komunikasi InterStudi berpengaruh terhadap peningkatan ekuitas merek.

$$
(\mathrm{r} \times \mathrm{y} \neq 0)
$$

\section{Metode Penelitian}

Pendekatan yang diguanakan dalam penelitian ini adalah kuantitatif. Metode yang digunakan eksplanatif, dan jenis penelitiannya adalah survey. Populasi penelitian ini adalah siswa STIKOM InterStudi sebanyak 1154 siswa dan 92 sampel siswa mengacu pada formula Taro Yamane dengan teknik Purposive Sampling. Data yang diolah dengan menggunakan SPSS 20.0 dengan Factor Analysis Menu, Alpha Cronbach, Statistik Deskriptif dan Statistik Inferensial kemudian disajikan pada tabel frekuensi, nilai mean dan analisis regresi. Teknik pengumpulan data dilakukan secara primer dan sekunder. Secara primer dilakukan melalui observasi, penyebaran kuesioner, wawancara. Sedangkan secara sekunder dilakukan melalui kepustakaan dan dokumentasi. Untuk menganalisis data digunakan Metode Campuran (Mixed Methods). Penelitian metode campuran adalah suatu rancangan yang baik untuk digunakan jika kita mencoba mendasarkan pada kekuatan data kuantitatif maupun kualitatif. Rancangan penelitian metode campuran (mixed methods research design) adalah suatu prosedur untuk mengumpulkan, menganalisis, "dan mencampur" metode kuantitatif dan kualitatif dalam suatu penelitian atau serangkaian penelitian untuk memahami permasalahan penelitian (Cresswell \& Plano Clark, 2011).

\section{Pembahasan}

Untuk menjawab tujuan penelitian sebagaimana yang telah dikemukakan sebelumnya, maka data yang diperoleh di lapangan analisa atau pembahasannya akan dibagi menjadi dua, yaitu profil responden. Profil ini dianggap penting untuk mengetahui identitas responden. Kemudian akan dibahas dan diinterpretasikan secara mendalam tentang strategi promosi STIKOM InterStudi berpengaruh terhadap peningkatan ekuitas merek, berikut adalah pembahasannya

\section{Profil Responden}

Profil responden terdiri dari jenis kelamin, usia, konsentrasi pendidikan dan tahun angkatan mahasiswa STIKOM InterStudi, berikut adalah deskripsinya.

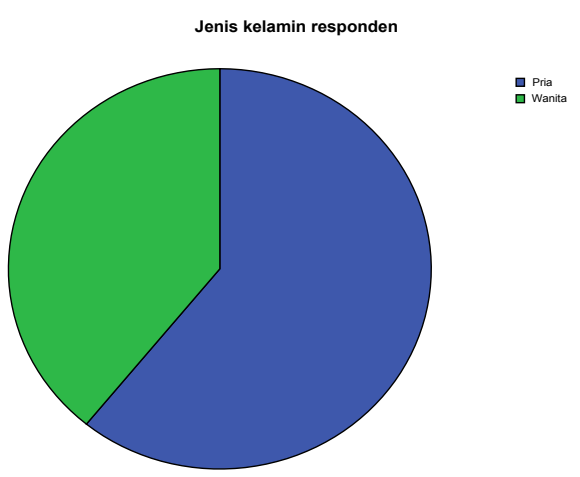

\section{Gambar 1. Grafik Pie Jenis Kelamin Responden}

Dari grafik pie di atas, terlihat bahwa karakteristik responden, dilihat dari segi jenis kelamin, maka mayoritas responden dengan prosentase lebih dari setengah jumlah responden adalah pria, kemudian sisanya adalah perempuan. Maka dengan demikian, responden terbanyak di dalam penelitian ini, dilihat 
dari jenis kelaminnya adalah pria. Perbedaan tersebut sesungguhnya tidak teralu signifikan dan hal ini dimungkinkan oleh faktor kebetulan saja ditambah lagi jumlah Mahasiswa/i STIKOM InterStudi bila dilihat dari gender, tidak ada yang mendominasi baik pria maupun wanita.

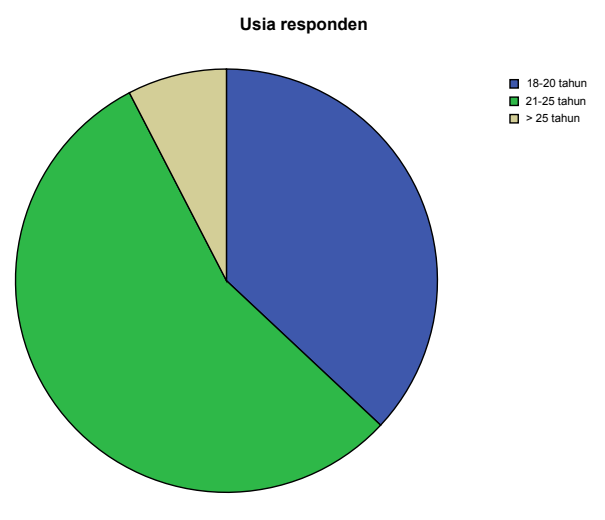

\section{Gambar 2. Grafik Pie Usia Responden}

Dari grafik pie di atas, tergambar bahwa dilihat dari segi usia, maka mayoritas responden terbanyak adalah responden yang berusia 21-25 tahun. sedangkan responden terdikit adalah yang berusia $>25$ tahun.

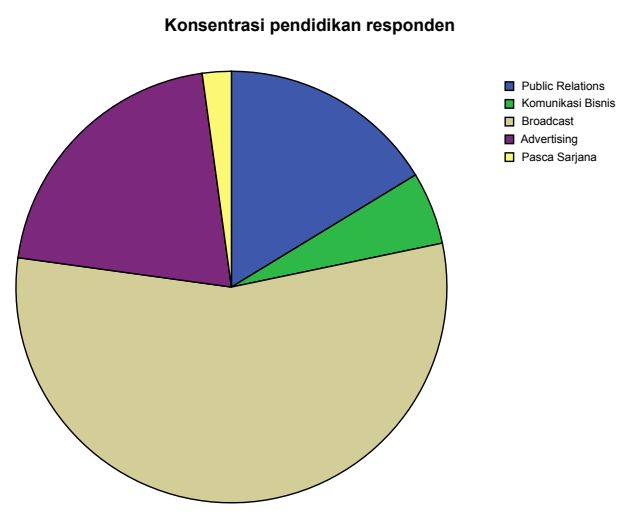

\section{Gambar 3. Grafik Pie Konsentrasi Pendidikan Responden}

Dari grafik pie di atas, tergambar bahwa mayoritas responden dengan prosentase lebih dari setengah jumlah responden berasal dari jurusan Broadcast (penyiaran). Sedangkan responden terdikit datang dari kalangan Pasca Sarjana. Hal ini dapat dikaitkan dengan keberadaan jurusan Broadcast (penyiaran) yang memang memiliki jumlah mahasiswa/I paling banyak dibanding dengan jurusan lainnya, sehingga wajar apabila dalam penelitian ini, mayoritas responden berasal dari jurusan Broadcast (penyiaran) dapat dilihat dalam grafik fi bawah ini

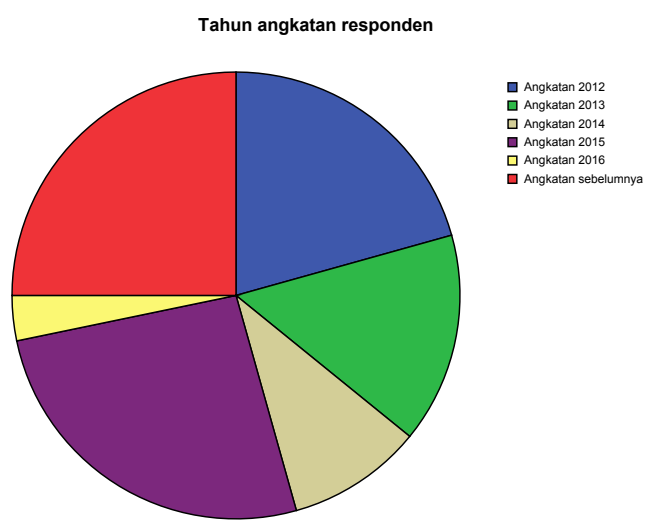

\section{Gambar 4.Grafik Pie Profesi Responden}

Dari grafik pie di atas, tergambar bahwa terjadi distribusi yang merata di mana responden terbanyak berasal dari tahun angkatan 2015. Sedangkan responden terdikit datang dari kalangan angkatan 2016. Hal ini juga dapat dikaitkan dengan keberadaan para mahasiswa/I pada angkatan tersebut di mana pada saat ini mereka pada semester empat dan sedang disibukkan dengan perkuliahan dan kegiatan kemahasiswaan sehingga angkatan tersebutlah yang lebih sering muncul dan beredar di kampus dan sekitarnya. 
Setelah membahas mengenai identitas responden, maka tahap selanjutnya adalah analisis regresi dengan tujuan melihat pengaruh Strategi Promosi Stikom InterStudi terhadap Peningkatan Ekuitas Merek.

\section{Dimensi dari variabel strategi promosi STIKOM InterStudi berpengaruh terhadap peningkatan ekuitas merek}

Analisis multivariat ini digunakan di dalam penelitian ini, untuk mengetahui dimensi apa dari variabel Strategi Promosi yang paling berpengaruh terhadap variabel Ekuitas Merek. Dimensi tersebut yaitu: Advertising $\left(\mathrm{X}_{1}\right)$, Word Of Mouth $\left(\mathrm{X}_{2}\right)$, Digital Advertising $\left(\mathrm{X}_{3}\right)$. Untuk menguji apakah variabel bebas $\left(\mathrm{X}_{1}, \mathrm{X}_{2}\right.$ dan $\left.\mathrm{X}_{3}\right)$ secara parsial memiliki pengaruh yang signifikan terhadap variabel terikat (Ekuitas Merek) maka akan dilihat melalui nial Sig. yang tertera pada tabel Anova di bawah berikut ini:

ANOVA

\begin{tabular}{|c|c|c|c|c|c|c|}
\hline Model & & $\begin{array}{l}\text { Sum of } \\
\text { Squares }\end{array}$ & df & Mean Square & $\mathrm{F}$ & Sig. \\
\hline \multirow[t]{3}{*}{1} & Regression & 934.753 & 3 & 311.584 & 8.450 & $.000^{a}$ \\
\hline & Residual & 3244.899 & 88 & 36.874 & & \\
\hline & Total & 4179.652 & 91 & & & \\
\hline
\end{tabular}

a. Predictors: (Constant), Digital Advertising, Word of Mouth, Advertising

b. Dependent Variable: EKUITAS MEREK

(Sumber data: Kuesioner 2017)

Oleh karena Sig. $<0,05$, maka $\mathrm{Ho}$ ditolak dan $\mathrm{Ha}$ diterima. Artinya Dimensi Strategi Promosi yaitu: Advertising $\left(\mathrm{X}_{1}\right)$, Word Of Mouth $\left(\mathrm{X}_{2}\right)$, Digital Advertising $\left(\mathrm{X}_{3}\right)$ secara parsial memiliki pengaruh signifikan terhadap Ekuitas Merek.

Dari ke tiga dimensi tersebut di atas, yakni Advertising $\left(\mathrm{X}_{1}\right)$, Word $O f$
Mouth $\left(\mathrm{X}_{2}\right)$, Digital Advertising $\left(\mathrm{X}_{3}\right)$, maka untuk melihat dimensi mana yang paling berpengaruh secara signifikan dalam meningkatkan Ekuitas Merek, maka akan dilihat dari nilai Sig. masingmasing dimensi pada tabel coefficient dalam analisis regresi berganda berikut ini:

\section{Coefficients $^{\mathrm{a}}$}

\begin{tabular}{|c|c|c|c|c|c|c|}
\hline \multirow[b]{2}{*}{ Mod } & & \multicolumn{2}{|c|}{$\begin{array}{l}\text { Unstandardized } \\
\text { Coefficients }\end{array}$} & \multirow{2}{*}{$\begin{array}{l}\text { Standardized } \\
\text { Coefficients } \\
\text { Beta }\end{array}$} & \multirow[b]{2}{*}{$\mathrm{t}$} & \multirow[b]{2}{*}{ Sig. } \\
\hline & & $B$ & Std. Error & & & \\
\hline \multirow[t]{4}{*}{$\overline{1}$} & (Constant) & 14.279 & 5.571 & & 2.563 & .012 \\
\hline & Advertising & -.078 & .143 & -.064 & -.548 & .585 \\
\hline & Word of Mouth & .431 & .098 & .474 & 4.412 & .000 \\
\hline & Digital Advertising & .064 & .130 & .057 & .492 & .624 \\
\hline
\end{tabular}

a. Dependent Variable: EKUITAS MEREK

(Sumber data: Kuesioner 2017) 
Dari masing-masing dimensi tersebut di atas mengartikan bahwa tidak semua dimensi pada variabel Strategi Promosi memiliki pengaruh signifikan dalam meningkatkan Ekuitas Merek. Adapun dimensi yang secara parsial memiliki pengaruh signifikan dalam meningkatkan Ekuitas Merek adalah dimensi Word Of Mouth $\left(\mathrm{X}_{2}\right)$, sedangkan dua dimensi lainnya yakni: Advertising $\left(\mathrm{X}_{1}\right)$ dan Digital Advertising $\left(\mathrm{X}_{3}\right)$ secara parsial tidak memiliki pengaruh yang signifikan dalam meningkatkan Ekuitas Merek STIKOM InterStudi.

\section{Grafik Garis Kontinum Strategi Promosi STIKOM InterStudi}

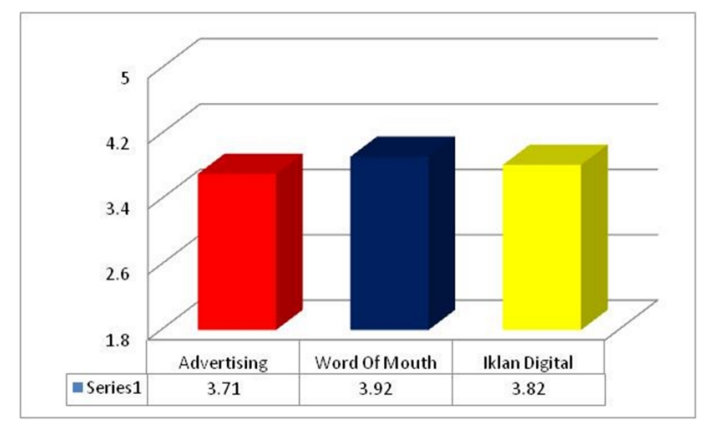

Dari data di atas, terlihat bahwa nilai tertinggi dengan skor 3,92 berada pada dimensi Word Of Mouth. Kemudian, nilai terendah dengan skor 3,71 berada pada dimensi Advertising. Dengan demikian, maka dimensi Word Of Mouth menjadi dimensi yang memiliki nilai paling tinggi di antara ke dua dimensi lainnya. Hal ini sejalan dengan hasil analisis regresi berganda yang memberikan hasil bahwa hanya Word Of Mouth $\left(\mathrm{X}_{2}\right)$, yang secara parsial memiliki pengaruh signifikan dalam meningkatkan Ekuitas Merek. Dengan kata lain, baik dilihat melalui analisis regresi berganda, maupun analisis rata-rata, ke dua-duanya menunjukkan bahwa hanya Word of Mouth $\left(\mathrm{X}_{2}\right)$, yang secara parsial memiliki pengaruh signifikan dalam meningkatkan Ekuitas Merek, sedangkan dua dimensi lainnya, yakni: Advertising $\left(\mathrm{X}_{1}\right)$ dan Digital Advertising $\left(\mathrm{X}_{3}\right)$ secara parsial tidak memiliki pengaruh yang signifikan dalam meningkatkan Ekuitas Merek.

Hasil tersebut di atas yang menunjukkan bahwa dimensi Word Of Mouth-lah yang secara parsial memiliki pengaruh yang signifikan dalam meningkatkan Ekuitas Merek tentunya senada dengan perkembangan yang terjadi di mana Word Of Mouth sebagai promosi dari mulut ke mulut yang selalu menjadi fenomena pemasaran yang menarik untuk dibicarakan, beberapa pemasar mempunyai pandangan yang skeptis dan meremehkan bentuk promosi tersebut, padahal promosi ini seringkali tidak memerlukan biaya yang besar seperti halnya berbagai bentuk promosi lainnya.

\section{Kesimpulan}

1. Strategi Promosi yang dibuat STIKOM InterStudi memiliki pengaruh dalam meningkatkan Ekuitas Merek, hanya saja pengaruh tersebut berada dalam kadar sangat rendah dengan prosentase nilai kontribusinya hanya sebesar $14,3 \%$. Sementara sisanya, sebanyak $\quad 85,7 \%$ dipengaruhi oleh faktor-faktor lain yang tidak diteliti dalam penelitian ini.

2. Dimensi yang secara parsial memiliki pengaruh signifikan dalam meningkatkan Ekuitas Merek adalah dimensi Word Of Mouth $\left(\mathrm{X}_{2}\right)$, sedangkan dua dimensi lainnya yakni: Advertising $\left(\mathrm{X}_{1}\right)$ dan Digital Advertising $\left(\mathrm{X}_{3}\right)$ secara parsial tidak memiliki pengaruh yang signifikan dalam meningkatkan Ekuitas Merek STIKOM InterStudi 


\section{Saran}

Untuk memberikan kontribusi pemikiran kepada STIKOM InterStudi, maka perlu diperlihatkan strategi promosi dalam bentuk Word Of Mouth karena sesuatu yang dibicarakan oleh konsumen perihal suatu produk akan berimbas pada citra produk tersebut, oleh sebab itu STIKOM InterStudi harus mampu memberikan rangsangan kepada khalayak sasaran agar termotivasi untuk melakukan pembicaraan yang positif dengan mengembangkan WOM melalui talking, promoting dan selling serta menciptakan WOM melalui $B e$ Interesting, Make it Easy, Make People Happy serta Earn Trust and Respect.

\section{Daftar Pustaka}

Aaker, David. 2014. Aaker On Branding : 20 prinsip Esensial Mengelola dan Mengembangkan Brand. Jakarta : PT. Gramedia Pustaka Utama

Amstrong, Gary and Kotler, Philip. 2001. Principle of Marketing. USA Publisher : Prentice Hall PTR.

Andi. 2004. Pengolahan Data Dengan Menggunakan SPSS 12.0. Yogyakarta: PT. Wahana Cipta.

Arifin, Anwar. 2003. Ilmu Komunikasi : Sebuah Pengantar Ringkas. Jakarta : PT. Raja Grafindo Persada.

Basu, Swastha. Irawan. 2001. Manajemen Pemasaran Modern : Yoyakarta : Liberty.

Belch, George E. dan Michael A. Belch. 2011. Introduction to Advertising and Promotion : An Integrated Marketing Communication Perspective. Publisher : Irwin/McGraw-Hill， $9^{\text {th }}$ Revised Edition.

Bungin, Burhan. 2005. Metodologi Penelitian Kuantitatif : Komunikasi,
Ekonomi dan Kebijakan Publik serta Ilmu-ilmu Sosial Lainnya. Jakarta : Kencana Prenada Media Group.

Cresswell, John W. 2015 Riset Pendidikan edisi 5, Yoyakarta : Pustaka Pelajar

Duncan, Tom. 2012. IMC using Advertising \& Promotion to build brands : International Edition

Durianto, Darmadi, Sugiarto \& Tony Sitinjak. 2001. Strategi Menaklukan Pasar melalui Riset Ekuitas dan Perilaku Merek. Jakarta : Gramedia Pustaka Utama.

Effendy, Onong Uchjana. 2007. Ilmu Komunikasi, Teori dan Praktek : Bandung : Remaja Rosdakarya.

Griffin, Jill. 2005. Customer Loyalty : Jakarta : Erlangga.

Ghozali Imam. 2007. Aplikasi Analisis Multivariat Dengan Program SPSS. Semarang: Badan Penerbit Universitas Diponegoro.

Jefkins, Frank. 1996. Periklanan (terjemahan dari Harcourt College Publisher). Jakarta : Erlangga.

Kasali, Rhenald. 1999. Membidik Pasar Indonesia : Segmentasi, Targeting dan Positioning. Jakarta : PT. Gramedia Pustaka Utama.

Kapferer, Jean-Noel. 2008. The New Strategic Brand Management : creating and sustaining brand equity long term. London \& Philadelphia : Kogan Page Limited.

Keller, Kevin Lane. 2013. Strategic Brand Management : Building, Measuring and Managing Brand Equity. England : Pearson Education Limited.

Kotler, Philip. Keller, K Lane. 2008. Manajemen Pemasaran : Jakarta : Erlangga

Kriyantono, Rachmat. 2006. Teknik Praktis Riset Komunikasi : Disertai Contoh Praktis Riset Media, Public Relations, Advertising, Komunikasi 
Organisasi, Komunikasi Pemasaran. Jakarta : Rawamangun.

Liliweri, Jalaludin. 1992. Dasar-dasar Komunikasi Periklanan. Bandung : PT. Citra Aditya.

Morissan, M A. 2010. Periklanan : Komunikasi Pemasaran Terpadu. Jakarta : Kencana Prenada Media Group.

Mulyana, Deddy. 2005. Ilmu Komunikasi. Suatu Pengantar. Cetakan Ketiga. Bandung : PT. Remaja Rosdakarya.

Rangkuty, Freddy. 2009. Strategi Promosi yang Kreatif \& Analisis

Kasus Integrated Marketing Communication : Jakarta : PT. Gramedia Pustaka Utama.

Riduwan. 2004. Skala Pengukuran Variabel-Variabel Penelitian. Bandung : Alfabeta.

Santoso, Singgih, 2010. Statistik Multivariat, Konsep dan Aplikasi dengan SPSS, Penerbit PT Elex Media Komputindo, Jakarta.

Shimp, Terence A. 2003. Periklanan Promosi Aspek Tmbahan Komunikasi Pemasaran Terpadu. Jakarta : Erlangga.

Singarimbun, Masri. 1989. Metode Penelitian Survai. Jakarta : LP3ES.

Sugiyono. 2002. Metode Penelitian Admi

nistrasi. Bandung : Alfabeta.

Sulaksana, Uyung. 2003. Komunikasi Pemasaran. Yogyakarta: Pustaka Pelajar.

Tjiptono, Fandy. 2005. Brand Management \& Strategy : Yogyakarta : An

\section{Sumber lain}

Jurnal

Ariyanti, Tria. 2014. "Pengaruh Strategi Promosi Terhadap Penjualan Produk di PT. United Indo Surabaya.Surabaya : Sekolah Tinggi Ilmu Ekonomi Surabaya
Darmawansyah, Surya. 2013. "Strategi Promosi dalam Meningkatkan Jumlah Mahasiswa pada Politeknik Negeri Media Kreatif Makassar. Makassar : Universitas Satria, Makassar.

Haryanto, Resty Avita. 2012. "Strategi Promosi, Kualitas Produk, Kualitas Layanan terhadap Kepuasan Pelanggan pada Restoran Mcdonald's Manado. Manado : Universitas Sam Ratulangi.

\section{Internet}

http://blogger-

viens.blogspot.co.id/2013/01/strateg i-promosi.html

(https://bisfren.com/jurusan-ilmukomunikasi.html 